\title{
The Effect of Acetoacetate on Plasma Insulin Concentration
}

\author{
By R. A. HAWKINS, K. G. M. M. ALBERTI, C. R. S. HOUGHTON, \\ D. H. WILLIAMSON AND H. A. KREBS \\ Metabolic Research Laboratory, Nuffield Department of Clinical Medicine, Radcliffe Infirmary, \\ Oxford OX2 6HE, U.K.
}

(Received 15 July 1971)

\begin{abstract}
1. Sodium acetoacetate was infused into the inferior vena cava of fed rats, $48 \mathrm{~h}$ starved rats, and fed streptozotocin-diabetic rats treated with insulin. Arterial blood was obtained from a femoral artery catheter. 2. Acetoacetate infusion caused a fall in blood glucose concentration in fed rats from 6.16 to $5.11 \mathrm{~mm}$ in $1 \mathrm{~h}$, whereas no change occurred in starved or fed-diabetic rats. 3. Plasma free fatty acids decreased within $10 \mathrm{~min}$, from 0.82 to 0.64 mequiv./ 1 in fed rats, 1.16 to 0.79 mequiv./ 1 in starved rats and 0.83 to 0.65 mequiv./1 in fed-diabetic rats. 4 . At $10 \mathrm{~min}$ the plasma concentration rose from 20 to $49.9 \mu \mathrm{units} / \mathrm{ml}$ in fed unanaesthetized rats and from 6.4 to $18.5 \mu \mathrm{units} / \mathrm{ml}$ in starved rats. There was no change in insulin concentration in the diabetic rats. 5. Nembutal-anaesthetized fed rats had a more marked increase in plasma insulin concentration, from 30 to $101 \mu \mathrm{units} / \mathrm{ml}$ within $10 \mathrm{~min}$. 6. A fall in blood glucose concentration in fed rats and a decrease in free fatty acids in both fed and starved rats is to be expected as a consequence of the increase in plasma insulin. 7. The fall in the concentration of free fatty acids in diabetic rats may be due to a direct effect of ketone bodies on adipose tissue. A similar effect on free fatty acids could also be operative in normal fed or starved rats.
\end{abstract}

Experimental elevation of the blood concentrations of 3-hydroxybutyrate or acetoacetate in many species causes a decrease in the concentration of glucose and plasma free fatty acids (Neptune, 1956; Madison, Mebane, Unger \& Lochner, 1964; Balasse, Couturier \& Franckson, 1967; Björntorp \& Scherstén, 1967; Senior \& Loridan, 1968; Devecerski, Pierce \& Frawley, 1968) and an increase in plasma insulin concentrations (Madison et al. 1964; Pi-Sunyer, Campbell \& Hashim, 1970). The rise in the insulin concentrations, however, has not been observed under all conditions (Balasse et al. 1967; Balasse \& Ooms, 1968; Devecerski et al. 1968; Loridan \& Senior, 1970; Senior \& Loridan, 1968).

In previous experiments, where circulating ketone-body concentrations of fed rats were raised by infusing acetoacetate, it was noted that the glucose concentration was lower than normal in fed rats (Hawkins, Williamson \& Krebs, 1971). Further experiments showed that this observation could be accounted for by a stimulatory effect of acetoacetate on insulin secretion as described by the previous workers. Experiments described in the present paper show that infusion of acetoacetate into fed rats at rates sufficient to maintain ketonebody concentrations between 2 and $3 \mathrm{~mm}$ or between 6 and $7 \mathrm{~mm}$ uniformly resulted in elevated peripheral insulin concentrations. Other changes in metabo. lite concentrations were as expected in the presence of increased insulin concentrations.

\section{MATERIALS AND METHODS}

Rats. Female rats of the Wistar strain weighing 200$250 \mathrm{~g}$ were used. They had free access to food unless otherwise indicated.

Reagents and analytical methods. ${ }^{125}$ I-labelled insulin was obtained from Abbott Laboratories, North Chicago, IIl., U.S.A. Guinea-pig anti-insulin serum was a gift from Dr P. H. Wright, University of Indiana School of Medicine, Indianapolis, Ind., U.S.A. Goat anti-guinea-pig serum and protamine zinc insulin were obtained from Wellcome Laboratories, Beckenham, Kent, U.K. Streptozotocin was a gift of the Upjohn Co., Kalamazoo, Mich., U.S.A. Rat insulin was obtained from Novo, Copenhagen, Denmark.

Sodium acetoacetate for infusion was prepared from ethyl acetoacetate as described by Krebs \& Eggleston (1941). It contained no ethanol when analysed by the method of Dickinson \& Dalziel (1967).

Determination of metabolites and insulin. The following metabolites were determined in whole blood by standard enzymic methods: lactate and pyruvate (Hohorst, Kreutz \& Bücher, 1959); acetoacetate and 3-hydroxybutyrate (Williamson, Mellanby \& Krebs, 1962); glucose (Slein, 1963). Free fatty acids were determined in plasma (Itaya \& Ui, 1965), as was insulin (Morgan \& Lazarow, 1963, as modified by Soeldner \& Sloane, 1965). Rat insulin was used as a reference standard. 
Diabetic rats. Rats were made diabetic by injection of $150 \mathrm{mg}$ of streptozotocin $/ \mathrm{kg}$ into the tail vein, a dose sufficient to eliminate pancreatic $\beta$-cell function (Junod, Lambert, Stauffacher \& Renold, 1969). One day after injection, all rats were severely diabetic with urine glucose concentrations of greater than $0.5 \%$ (Clinistix test, Miles Laboratories Ltd., Elkart, Ind., U.S.A.). They were then given 2-3 units of protamine zinc insulin at 4.30 p.m. each day for a period of 7 days. The dose was adjusted to each rat's requirement on the basis of weight maintenance and the presence of glucose and ketone bodies in the urine as tested with Clinistix and Ketostix. The rats lost an average of $12 \mathrm{~g}$ the first day but maintained constant weight thereafter.

Infusion of acetoacetate and collection of blood. Two days before the experiment the rats were placed in restraining cages to allow familiarization with the cage conditions. On the penultimate day the rats were anaesthetized with diethyl ether and catheters were placed in the femoral artery and vein as previously described (Hawkins et al. 1971). Acetoacetate was infused at either $150 \mu \mathrm{mol} / \mathrm{min}$ per $\mathrm{kg}$ for $10 \mathrm{~min}$ and $75 \mu \mathrm{mol} / \mathrm{min}$ per $\mathrm{kg}$ thereafter to produce blood concentrations of ketone bodies in fed rats comparable with those occurring after $48 \mathrm{~h}$ starvation (2-3 mm) or at rates double those stated to produce abnormally high ketone-body concentrations (6-7 mM). Blood $(0.25-0.45 \mathrm{ml})$ was sampled at intervals from the arterial catheter and coagulation was retarded by adding $0.2 \mathrm{~m}$ neutral EDTA to a final concentration of 3-5 mM. Between sampling the cannulae were kept open with $0.154 \mathrm{~m}-\mathrm{NaCl}$. The total amount of blood removed from a rat never exceeded $1.8 \mathrm{ml}$. A portion $(0.1 \mathrm{ml})$ of the blood was acidified in $2 \mathrm{ml}$ of $0.3 \mathrm{M}-\mathrm{HClO}_{4}$ for metabolite measurements. The plasma from the remainder was separated immediately by centrifugation for measurement of free fatty acids and insulin.

Anaesthetized rats. All experiments were done on conscious rats with the exception of one group which were anaesthetized with $30 \mathrm{mg}$ of freshly made Nembutal aqueous solution $/ \mathrm{kg}$ administered intravenously $45 \mathrm{~min}$ before infusion.

\section{RESULTS}

Blood metabolite concentrations in restrained, catheterized rats. The method by which blood samples are taken and the treatment of rats may affect metabolite concentrations. Table 1 contains a comparison of metabolite concentrations of mixed blood from unanaesthetized decapitated rats, arterial blood of freshly anaesthetized rats $(50 \mathrm{mg}$ of Nembutal/kg administered $30-45 \mathrm{~min}$ before sampling) and arterial blood of conscious restrained rats prepared as described in the Materials and Methods section.

The concentrations of glucose and free fatty acids did not differ between the various conditions in either the fed or the starved group.

Blood from decapitated rats was primarily venous and the lactate concentrations were higher than arterial blood in both fed and starved rats. This is probably due to anoxia and the consequent high rate of lactate production that inevitably occurs after decapitation. The arterial lactate concentration of fed restrained rats was about half that of fed anaesthetized rats. Starved restrained rats had arterial lactate concentrations about $67 \%$ higher than blood of anaesthetized rats.

The concentration of ketone bodies in fed restrained rats was three- to four-fold higher and starved restrained rats had concentrations 1.27$1.72 \mathrm{~mm}$ higher than either anaesthetized rats or

\section{Table 1. Blood metabolites obtained under various conditions in fed and $48 \mathrm{~h}$-starved rats}

The results are mean values ( \pm S.D.) with the number of observations in each group in parentheses. Fed and starved decapitated rats were unanaesthetized and blood was obtained on exsanguination. Anaesthetized rats were given an intraperitoneal injection of Nembutal $(50 \mathrm{mg} / \mathrm{kg}) 30-45 \mathrm{~min}$ before blood was obtained from the femoral artery. Conscious rats were restrained for 2 days before sampling and had an arterial catheter placed in the femoral artery on the penultimate day.

\begin{tabular}{|c|c|c|c|c|c|c|c|}
\hline nditions & $\begin{array}{l}\text { Glucose } \\
\text { (mM) }\end{array}$ & $\begin{array}{l}\text { Lactate } \\
\text { (mM) }\end{array}$ & $\begin{array}{l}\text { Pyruvate } \\
\text { (mM) }\end{array}$ & $\begin{array}{l}\text { 3-Hydroxy- } \\
\text { butyrate } \\
\text { (mM) }\end{array}$ & $\begin{array}{l}\text { Aceto- } \\
\text { acetate } \\
\text { (mM) }\end{array}$ & $\begin{array}{c}\text { ketone } \\
\text { bodies } \\
\text { (mM) }\end{array}$ & $\begin{array}{c}\text { fatty } \\
\text { aoids } \\
\text { (mequiv./l) }\end{array}$ \\
\hline pitated, mixed & $6.14 \pm 0.14$ & $1.76 \pm 1.43$ & $0.142 \pm 0.070$ & $0.03 \pm 0.03$ & $0.12 \pm 0.01$ & 0.15 & $0.64 \pm 0.23$ \\
\hline thetized, arterial & $6.34 \pm 0.47$ & $1.10 \pm 0.57$ & $0.141 \pm 0.053$ & $0.09 \pm 0.04$ & $0.13 \pm 0.03$ & 0.22 & - \\
\hline $\begin{array}{l}\text { oious, arterial } \\
\text { 3) }\end{array}$ & $6.26 \pm 0.62$ & $0.59 \pm 0.23$ & $0.098 \pm 0.057$ & $0.26 \pm 0.18$ & $0.39 \pm 0.16$ & 0.65 & $0.66 \pm 0.35$ \\
\hline $\begin{array}{l}\text { d, decapitated, } \\
\text { lood (6) }\end{array}$ & $4.06 \pm 0.21$ & $2.15 \pm 0.71$ & $0.234 \pm 0.075$ & $1.83 \pm 0.53$ & $0.53 \pm 0.09$ & 2.36 & $1.42 \pm 0.34$ \\
\hline $\begin{array}{l}\text { d, anaesthetized, } \\
\text { blood (10) }\end{array}$ & $4.76 \pm 0.92$ & $0.54 \pm 0.15$ & $0.059 \pm 0.008$ & $2.00 \pm 0.49$ & $0.81 \pm 0.16$ & 2.81 & - \\
\hline $\begin{array}{l}\text { d, conscious, } \\
\text { blood (13) }\end{array}$ & $3.87 \pm 0.56$ & $0.90 \pm 0.28$ & $0.120 \pm 0.035$ & $2.63 \pm 0.91$ & $1.45 \pm 0.29$ & 4.08 & $1.31 \pm 0.38$ \\
\hline
\end{tabular}


decapitated rats. The reason for this is not clear.

Infusion of acetoacetate into normal fed rats. Infusion of acetoacetate to raise the total ketonebody concentration to values approximating to those found in starvation (2-3 mM) did not change the arterial glucose concentration significantly (Table 2). The plasma insulin concentration rose by $53 \%$ within $10 \mathrm{~min}$ and decreased slightly throughout the remainder of the infusion period. Rapid acetoacetate infusion resulting in higher concentrations (6-7 mM) depressed the glucose concentration within $10 \mathrm{~min}$ by $0.61 \mathrm{~mm}$ and by $1.05 \mathrm{~mm}$ at $60 \mathrm{~min}$. This was accompanied by a $150 \%$ rise in plasma insulin during the first $10 \mathrm{~min}$ and a decrease in free fatty acids.

Nembutal-anaesthetized rats. Anaesthetized rats infused at the rapid rate showed a similar pattern but the increase in plasma insulin concentration was greater than in unanaesthetized rats throughout the infusion period $(P<0.1,0.025$ and 0.05 at 10,30 and $60 \mathrm{~min}$ respectively).

Infusion of fed-diabetic rats. The fed, insulintreated diabetic rats showed no consistent change in blood glucose on acetoacetate infusion at the high rate. The concentration of plasma insulin remained constant, as was to be expected. However, free fatty acids decreased by $23 \%$ within $10 \mathrm{~min}$ and remained constant thereafter.
Infusion of normal starved rats. Infusion of acetoacetate into $48 \mathrm{~h}$-starved rats at the high rate resulted in an increase of total ketone bodies from $3.88 \mathrm{~mm}$ to $10.8 \mathrm{~mm}$ in $10 \mathrm{~min}$ (Table 3). At $30 \mathrm{~min}$ after the infusion was terminated the ketonebody concentrations were about twice their original value $(7.58 \mathrm{~mm})$. There was no significant change in blood glucose throughout the experiment, but there was a threefold rise in the plasma insulin concentration, which was maintained until the infusion was stopped at $30 \mathrm{~min}$, whereupon the insulin concentration returned to normal by $60 \mathrm{~min}$. Free fatty acid concentrations decreased by $32 \%$ within $10 \mathrm{~min}$ and remained low throughout.

\section{DISCUSSION}

The results presented here show that plasma insulin concentrations increase. when the blood ketone-body concentrations are raised from less than $1 \mathrm{~mm}$ to $2-3 \mathrm{~mm}$ or $6-7 \mathrm{~mm}$ in fed rats and from $3 \mathrm{~mm}$ to $11 \mathrm{~mm}$ in $48 \mathrm{~h}$-starved rats. This effect was much larger in fed rats than in starved ones, although in the fed state the initial concentrations of insulin were about 4-5 times higher than in the starved state. Madison et al. (1964), who first observed this effect on dogs, suggested that the stimulation of insulin secretion by ketone bodies

Table 2. Effect of acetoacetate infusion on circulating metabolite and insulin concentrations in fed rats

The results are mean values ( \pm s.E.M.) with the number of observations in each group in parentheses. The symbols* and ** indicate statistical significance, as compared with the initial value, of 5 and $1 \%$ respectively. Infusions were begun at zero time and continued throughout the experiment. For details see the Materials and Methods section.

\begin{tabular}{|c|c|c|c|c|c|c|}
\hline Conditions & $\begin{array}{l}\text { Time } \\
(\min )\end{array}$ & $\begin{array}{l}\text { Glucose } \\
(\mathbf{m m})\end{array}$ & $\begin{array}{l}\text { 3-Hydroxy- } \\
\text { butyrate } \\
\text { (mM) }\end{array}$ & $\begin{array}{l}\text { Aceto- } \\
\text { acetate } \\
(\mathrm{mM})\end{array}$ & $\begin{array}{l}\text { Free fatty } \\
\text { acids } \\
\text { (mequiv./l) }\end{array}$ & $\begin{array}{c}\text { Insulin } \\
\text { ( } \mu \text { units/ } \\
\text { ml) }\end{array}$ \\
\hline \multirow{4}{*}{ Acetoacetate-infused at slow rate (6) } & $\mathbf{0}$ & $6.78 \pm 0.24$ & $0.49 \pm 0.15$ & $0.47 \pm 0.09$ & - & $26.7 \pm 3.6$ \\
\hline & 10 & $6.72 \pm 0.43$ & $1.10 \pm 0.10$ & $2.63 \pm 0.22$ & - & $41.0 \pm 12.4^{*}$ \\
\hline & 20 & $6.44 \pm 0.09$ & $1.02 \pm 0.10$ & $2.27 \pm 0.14$ & 一 & $39.0 \pm 10.7 *$ \\
\hline & 60 & $6.72 \pm 0.16$ & $0.87 \pm 0.18$ & $2.00 \pm 0.19$ & 一 & $35.2 \pm 8.5$ \\
\hline \multirow{4}{*}{$\begin{array}{l}\text { Acetoacetate-infused at rapid rate } \\
\text { (9) }\end{array}$} & $\mathbf{0}$ & $6.16 \pm 0.19$ & $0.32 \pm 0.07$ & $0.50 \pm 0.04$ & $0.82 \pm 0.14$ & $20.0 \pm 2.7$ \\
\hline & 10 & $5.55 \pm 0.21 *$ & $0.92 \pm 0.07$ & $4.99 \pm 0.26$ & $0.73 \pm 0.10$ & $49.9 \pm 7.8^{*}$ \\
\hline & 30 & $5.21 \pm 0.24 * *$ & $1.11 \pm 0.10$ & $4.88 \pm 0.25$ & $0.65 \pm 0.10^{*}$ & $28.6 \pm 4.2$ \\
\hline & 60 & $5.11 \pm 0.24 * *$ & $1.25 \pm 0.11$ & $5.12 \pm 0.30$ & $0.64 \pm 0.07 *$ & $31.7 \pm 6.5$ \\
\hline \multirow{4}{*}{$\begin{array}{l}\text { Acetoacetate-infused at rapid rate, } \\
\text { Nembutal-anaesthetized (5) }\end{array}$} & 0 & $5.77 \pm 0.23$ & $0.22 \pm 0.06$ & $0.49 \pm 0.05$ & - & $30.0 \pm 7.1$ \\
\hline & 10 & $5.49 \pm 0.20$ & $1.08 \pm 0.11$ & $5.85 \pm 0.42$ & 一 & $101.2 \pm 26.3^{*}$ \\
\hline & 30 & $4.54 \pm 0.14 * *$ & $1.29 \pm 0.08$ & $6.01 \pm 0.52$ & 一 & $57.5 \pm 11.8 *$ \\
\hline & 60 & $4.64 \pm 0.28 *$ & $1.41 \pm 0.16$ & $6.19 \pm 0.90$ & - & $67.6 \pm 17.3^{*}$ \\
\hline \multirow{4}{*}{$\begin{array}{l}\text { Insulin-maintained diabetic rats, } \\
\text { acetoacetate-infused at rapid rate } \\
\text { (9) }\end{array}$} & $\mathbf{0}$ & $3.32 \pm 0.84$ & $0.19 \pm 0.06$ & $0.85 \pm 0.13$ & $0.83 \pm 0.13$ & $46.9 \pm 9.6$ \\
\hline & 10 & $3.76 \pm 0.99$ & $0.95 \pm 0.13$ & $5.43 \pm 0.71$ & $0.64 \pm 0.01 *$ & $43.0 \pm 8.9$ \\
\hline & 30 & $3.58 \pm 1.26$ & $1.12 \pm 0.12$ & $5.81 \pm 0.60$ & $0.58 \pm 0.08 * *$ & $32.6 \pm 8.8$ \\
\hline & 60 & $4.40 \pm 1.92$ & $1.57 \pm 0.26$ & $6.74 \pm 0.69$ & $0.65 \pm 0.06$ & $41.4 \pm 11.0$ \\
\hline \multirow[t]{4}{*}{$\mathrm{NaCl}$-infused (8) } & 0 & $5.98 \pm 0.19$ & $0.26 \pm 0.07$ & $0.35 \pm 0.04$ & $0.50 \pm 0.07$ & $28.7 \pm 5.5$ \\
\hline & 10 & $6.11 \pm 0.29$ & $0.27 \pm 0.06$ & $0.32 \pm 0.05$ & $0.47 \pm 0.08$ & $31.3 \pm 4.2$ \\
\hline & 30 & $6.12 \pm 0.22$ & - & $0.35 \pm 0.06$ & $0.48 \pm 0.11$ & $22.5 \pm 5.0$ \\
\hline & 60 & $6.11 \pm 0.24$ & $0.10 \pm 0.02$ & $0.36 \pm 0.05$ & $0.58 \pm 0.09$ & $30.0 \pm 4.3$ \\
\hline
\end{tabular}


Table 3. Effect of acetoacetate on blood metabolites and insulin concentration in $48 \mathrm{~h}$-starved rats

The results are mean values ( \pm s.F.m.) with the number of observations in each group in parentheses. The symbols * and ** indicate statistical significance as compared with the initial value, of 5 and $1 \%$ respectively. Infusions were begun at zero time and terminated after $30 \mathrm{~min}$. For details see the Materials and Methods section.

\begin{tabular}{|c|c|c|c|c|c|c|}
\hline Conditions & $\begin{array}{l}\text { Time } \\
(\min )\end{array}$ & $\begin{array}{l}\text { Glucose } \\
(\mathbf{m} \mathbf{M})\end{array}$ & $\begin{array}{l}\text { 3-Hydroxybutyrate } \\
\text { (mM) }\end{array}$ & $\begin{array}{l}\text { Acetoacetate } \\
\text { (mM) }\end{array}$ & $\begin{array}{l}\text { Free fatty } \\
\text { acids } \\
\text { (mequiv./l) }\end{array}$ & $\begin{array}{l}\text { Insulin } \\
\text { ( } \text { units/1) }\end{array}$ \\
\hline \multirow[t]{3}{*}{$\begin{array}{l}\text { Acetoacetate-infused } \\
\text { rapid rate (8) }\end{array}$} & $\begin{array}{r}0 \\
10\end{array}$ & $\begin{array}{l}4.00 \pm 0.19 \\
4.20 \pm 0.24\end{array}$ & $\begin{array}{l}2.44 \pm 0.33 \\
3.07 \pm 0.35\end{array}$ & $\begin{array}{l}1.44 \pm 0.11 \\
7.77 \pm 0.49\end{array}$ & $\begin{array}{l}1.16 \pm 0.14^{*} \\
0.79 \pm 0.13^{*}\end{array}$ & $\begin{array}{c}6.4 \pm 1.7 \\
18.5 \pm 3.5^{* *}\end{array}$ \\
\hline & 30 & $3.61 \pm 0.29$ & $3.23 \pm 0.35$ & $8.53 \pm 0.57$ & $0.80 \pm 0.10^{* *}$ & $18.5 \pm 5.4^{*}$ \\
\hline & 60 & $3.76 \pm 0.31$ & $3.64 \pm 0.45$ & $3.94 \pm 0.46$ & $0.77 \pm 0.10^{*}$ & $7.5 \pm 1.7$ \\
\hline \multirow[t]{4}{*}{$\mathrm{NaCl}$-infused (5) } & 0 & $3.66 \pm 0.31$ & $2.95 \pm 0.42$ & $1.47 \pm 0.16$ & $1.38 \pm 0.10$ & $4.2 \pm 1.0$ \\
\hline & 10 & $4.10 \pm 0.40$ & $2.84 \pm 0.31$ & $1.55 \pm 0.09$ & $1.32 \pm 0.17$ & $7.4 \pm 1.3$ \\
\hline & 30 & $3.83 \pm 0.42$ & $2.90 \pm 0.41$ & $1.44 \pm 0.14$ & $1.13 \pm 0.21$ & $5.8 \pm 1.0$ \\
\hline & 60 & $3.75 \pm 0.30$ & $3.09 \pm 0.47$ & $1.50 \pm 0.19$ & $1.23 \pm 0.20$ & $4.5 \pm 0.8$ \\
\hline
\end{tabular}

may be of importance in the feed-back regulation of ketone-body production. Increased insulin concentrations decrease the free fatty acid release from adipose tissue (see Scow \& Chernick, 1970) and therefore inhibit ketogenesis by lowering the concentrations of their precursors. In addition there is evidence that insulin may have a direct effect on hepatic ketogenesis (Bieberdorf, Chernick \& Scow, 1970).

A feed-back control not mediated by insulin appears to be a direct inhibition of free fatty acid release from adipose tissue by ketone bodies (Björntorp, 1966; Hellman, Senior \& Goodman, 1969). This effect occurs in alloxan-diabetic dogs where insulin is not likely to be involved (Björntorp \& Scherstén, 1967). The finding that infusion of acetoacetate decreased free fatty acid concentrations without any insulin change in streptozotocindiabetic rats (Table 2) confirms previous work. It is therefore likely that in normal animals the decrease of free fatty acids is due to the operation of both feed-back mechanisms.

This work was supported by grants from the Medical Research Council and from the U.S. Public Health Service (Grant no. AM 11748). D. H. W. is a member of the external staff of the Medical Research Council and R. A. H. is a U.S. Public Health Service Postdoctoral Research Fellow (Fo2-AM-30,273-01). K. G. M. M. A. is Research Officer at the Nuffield Department of Clinical Medicine, Radcliffe Infirmary, Oxford, and is supported by the Wellcome Trust.

\section{REFERENCES}

Balasse, E., Couturier, E. \& Franckson, J. R. M. (1967). Diabetologia, 3, 488.

Balasse, E. \& Ooms, H. A. (1968). Diabetologia, 4, 133.
Bieberdorf, F. A., Chernick, S. S. \& Scow, R. O. (1970). J. clin. Invest. 49, 1685.

Björntorp, P. (1966). J. Lipid Res. 7, 621.

Björntorp, P. \& Scherstén, T. (1967). Am.J. Physiol.212, 683.

Devecerski, M., Pierce, C. E. \& Frawley, T. F. (1968). Metabolism, 17, 877.

Dickinson, F. M. \& Dalziel, K. (1967). Biochem. J. 104, 165.

Hawkins, R. A., Williamson, D. H. \& Krebs, H. A. (1971). Biochem. J. 122, 13.

Hellman, D. E., Senior, B. \& Goodman, H. M. (1969). Metabolism, 18, 906.

Hohorst, H. J., Kreutz, F. H. \& Bücher, Th. (1959). Biochem. Z. 332, 18.

Itaya, K. \& Ui, M. (1965). J. Lipid Res. 6, 16.

Junod, A., Lambert, A. E., Stauffacher, W. \& Renold, A. E. (1969). J. clin. Invest. 48, 2129.

Krebs, H. A. \& Eggleston, L. V. (1941). Biochem. J. 39, 438.

Loridan, L. \& Senior, B. (1970). J. Pediat. 76, 69.

Madison, L. L., Mebane, D., Unger, R. H. \& Lochner, A. (1964). J. clin. Invest. 43, 408.

Morgan, C. R. \& Lazarow, A. (1963). Diabetes, 12, 115.

Neptune, E. M. (1956). Am. J. Physiol. 187, 451.

Pi-Sunyer, F. X., Campbell, R. G. \& Hashim, S. A. (1970). Metabolism, 19, 263.

Scow, R. O. \& Chernick, S. S. (1970). In Comprehensive Biochemistry, vol. 18, p. 20. Ed. by Florkin, M. \& Stotz, E. H. Amsterdam: Elsevier Publishing Co.

Senior, B. \& Loridan, L. (1968). Nature, Lond., 219, 83.

Slein, M. W. (1963). In Methods of Enzymatic Analysis, p. 117. Ed. by Bergmeyer, H. U. New York and London: Academic Press.

Soeldner, J. S. \& Slone, D. (1965). Diabetes, 14, 771.

Williamson, D. H., Mellanby, J. \& Krebs, H. A. (1962). Biochem. J. 82, 90. 